UDK 613.21/.25:641.1]:159.922.8-053.6

\title{
ALIGNING NUTRITION KNOWLEDGE AND DIETARY HABITS OF GENERATION Z-IS THERE A ROOM FOR IMPROVEMENT?
}

Szabolcs Halasi ${ }^{1}$, Miljana Z. Djordjević ${ }^{* 2,}$, Ferenc E. Kiss ${ }^{3}$, Dragana M. Šoronja-Simović ${ }^{2}$, Nikola R. Maravić ${ }^{2}$ Olga Horvat ${ }^{4}$, Žana Šaranović ${ }^{5}$

${ }^{1}$ University of Novi Sad, Hungarian Language Teacher Training Faculty, Department for Physical Education, 24000 Subotica, Štrosmajerova 11, Serbia

${ }^{2}$ University of Novi Sad, Faculty of Technology, Department of Carbohydrate Food Engineering, 21000 Novi Sad, Blvd. cara Lazara 1, Serbia

${ }^{3}$ University of Novi Sad, Faculty of Technology, Department of Basic Engineering Disciplines, 21000 Novi Sad, Blvd. cara Lazara 1, Serbia

${ }^{4}$ University of Novi Sad, Faculty of Medicine, Department of Pharmacology, Toxicology and Clinical Pharmacology, 21000 Novi Sad, Hajduk Veljkova 3, Serbia

${ }^{5}$ Economics Institute, 11000 Belgrade, Kralja Milana 16, Serbia

\begin{abstract}
The potential association between determinants such as nutrition knowledge and dietary habits with obesity development among adolescents of generation Z (Zoomers) was investigated in the presented study. Data regarding meals consumption frequency, snack choice and familiarity with amounts of basic food nutrients in diet were gathered throughout a self-designed questionnaire from 854 adolescents (11-18 years) attending elementary and secondary schools in the Autonomous Province of Vojvodina, Serbia. The corresponding data was analysed and discussed primarily concerning BMI-for-age, and subsequently, gender and educational stage. The association between BMI categories and examined determinants was tested using chi-square and multinomial logistic regression statistics. Although most of the surveyed adolescents had normal weight $(72.1 \%)$, a notable share of overweight adolescents was also detected (17.9\%). Additionally, observed irregularities in breakfast and dinner consumption frequencies and participants' modest nutrition knowledge can contribute to further diet deterioration. Statistically significant but weak associations between BMI-for-age and choice of snack, dinner consumption frequency, as well as the frequency of salty snack and fast food consumption, were noted. Furthermore, an increase in nutrition knowledge was inversely associated with obesity prevalence (OR 6.56, 95\% CI 1.388-31.037).

As an outcome, the need for improvement regarding studied determinants especially nutrition knowledge is established and represents a task to achieve through health promotion strategies among generation $\mathrm{Z}$.
\end{abstract}

Key words: Zoomers, nutrition knowledge, body mass index, meal habits, obesity 


\section{INTRODUCTION}

Adolescence represents a period of raising independence and self-determination in every life aspects including diet. Changes in dietary habits in this life stage are mostly directed towards nutrition deterioration and thus this period is recognized as a period of high nutritional risk (WHO, 2005). Typical adolescents' diet is characterised by excessive consumption of sweets, fatty, salty snacks and sugar-sweetened beverages and insufficient fruit and vegetable intake (Moreno et al., 2010; Rodrigues et al., 2017). As an outcome of the disbalance between the mentioned high caloric diet and energy consumption, the occurrence of overweight and obesity among adolescents nowadays represents a global issue (WHO, 2009). Furthermore, poor dietary habits established in adolescence tend to persist throughout one's life (Craigie, Lake, Kelly, Adamson, \& Mathers, 2011) increasing the risks for obesity into adulthood as well as the development of numerous associated longterm health implications (Wang \& Zhang, 2006).

The increasing intake of particular foods among adolescents is often connected with the availability of this food at school and school surrounding (Rovner, Nansel, Wang, \& Iannotti, 2011). Furthermore, the desire to be accepted and integrated into a group (Ton $\mathrm{Nu}$, MacLeod, \& Barthelemy, 1996) as well as peer's body image perception could also be correlated with adolescents' dietary habits deterioration (Stevenson, Doherty, Barnett, Muldoon, \& Trew, 2007). Adolescents' dissatisfaction with their body image is a driving force to undertake certain weight control strategies which are often inappropriate. Although the results of many studies imply that physical activity is the most effective weight control strategy (McGuire, Wing, Klem, \& Hill, 1999), breakfast skipping appears as a common weight control strategy among adolescents (Timlin, Pereira, Story, \& Neumark-Sztainer, 2008). Adolescents are more prone to skip or have an inappropriate breakfast compared to lunch or dinner (Alexy, Wicher, \& Kersting, 2010). However, the link found between the habit of meals skipping and increased body weight (Estima, Costa, Sichieri, Pereira, \& Veiga, 2009) could indicate the potential lack of nutrition knowledge among adolescents.
Nevertheless, the preferences of generation $Z$ (Gen $\mathrm{Z}$ or Zoomers) as the new leading generation have the potential to overcome this issue. The Zoomers are recognized as a community oriented, eco-friendly and health-aware generation striving towards sustainability due to the introduction of a healthy lifestyle in the early stage of life ( $\mathrm{Su}$, Tsai, Chen, \& Lv, 2019). The corresponding consciousness is also reflected in food choices and consequently adopted dietary habits. According to Alčaković (2019), aspirations of generation Z in Serbia which accounts for about $20 \%$ of the population, are directed towards health maintenance followed by a successful career whether in a company or own business. Considering their interest in nutrition and education, greater independence and tech-savvy skills they are positioned to gain the knowledge needed to make a proper food selection for daily consumption.

Tracking the impact of diverse factors affecting the adolescents' dietary habits and physical activity could be beneficial towards the development and implementation of strategies aiming to reduce adolescents' obesity. Alongside social and environmental factors, proper nutrition knowledge could play a crucial role in the development of healthy dietary habits and their adoption in adolescence. The paucity of studies reports the dietary habits and nutrition knowledge of Serbian adolescents. Therefore, the present study aims to fulfil the gap in the existing research and present the results addressing generation Z' dietary habits, and nutrition knowledge regarding their BMI. In addition, the study examined whether lack of nutrition knowledge could be connected with the unhealthy dietary habits development leading to overweight and obesity.

\section{MATERIALS AND METHODS}

\section{Study population}

The study was conducted during the spring of 2018 in elementary and secondary schools in the Autonomous Province of Vojvodina, Serbia. The target population were pupils attending $5^{\text {th }}$ (10-12 years) and $7^{\text {th }}$ (13-14 years) grade of elementary schools and $3^{\text {rd }}(17-18$ years) grade of secondary schools. Random sampling technique was used for participants' 
selection among 53669 pupils in the targeted population. Participating pupils were almost evenly distributed among the investigated grades. Surveyed sample included 854 individuals aged from 11 to 18 years from which 369 were boys $(43.2 \%)$ and 485 were girls $(56.8 \%)$. The majority of the participants were from rural area $(77.8 \%)$. An overview of the study population basic characteristics is presented in Table 1 .

Approval for access to participants was obtained by the Provincial Secretariat for Higher Education and Scientific Research of the Autonomous Province of Vojvodina. The survey was conducted upon gained approval by the directorship and parental council of the participating schools. Before questionnaire distribution, the background and intentions of the survey were explained and participants were encouraged to participate without any pressure. Participation was voluntary and anonymous while the obtained data were handled as confidential. Participants did not receive any special education regarding nutrition before completing the questionnaire.

\section{Questionnaire}

The authors' self-designed questionnaire enveloped several sections. In the first section demographic (gender, age, place of residence) and anthropometric data (weight $[\mathrm{kg}]$ and height $[\mathrm{m}]$ ) of the participants were collected.

The second section included questions regarding dietary habits such as frequency and regularity of weekly meal intake as well as preferable choice of snack (fruits, salty snacks

Table 1.

Overview of the study population basic characteristics i.e. chips, crisps, crackers, popcorn, cereal bars, sweets, supplements and energy bars or nothing). Furthermore, participants were asked to report how often they ate outside home (in a bakery, restaurant, and food from a fast food kiosk i.e. hamburger, pancakes, pizza, gyros).

Third section comprised of questions addressing nutrition knowledge such as questions regarding food nutrients requirements, food nutrients contents in targeted foodstuff and conversance related to healthy diet. The participants were asked to order basic food nutrients according to the amount needed in daily diet (regular order water, carbohydrates, proteins, fats, dietary fibres, vitamins and minerals) (Barr, 2006). Moreover, participants were asked to choose between pairs of selected foodstuff by marking one which contains one of the mentioned food nutrients in a higher amount.

Participants' ability to gather information from the surrounding environment (TV, magazines, internet) was assessed through questions about wholemeal bread and vitamin deficiency definitions. By selecting one of the offered responses, participants revealed their familiarity with the corresponding terms.

\section{Nutritional status assessment}

Based on the self-reported anthropometric data, body mass index (BMI) of the participants was calculated as weight in kilograms divided by the square of height in meters and applied for the participants' nutritional status assessment. Participants were classified into four categories underweight, normal, over-

\begin{tabular}{|c|c|c|c|c|c|c|}
\hline & \multicolumn{2}{|c|}{ Boys } & \multicolumn{2}{|c|}{ Girls } & \multicolumn{2}{|c|}{ Total } \\
\hline & $\mathrm{n}$ & $\%$ & $\mathrm{n}$ & $\%$ & $\mathrm{n}$ & $\%$ \\
\hline \multicolumn{7}{|l|}{ Educational stage } \\
\hline Elementary school $5^{\text {th }}$ grade & 134 & 15.7 & 143 & 16.7 & 277 & 32.4 \\
\hline Elementary school $7^{\text {th }}$ grade & 120 & 14.1 & 147 & 17.2 & 267 & 31.3 \\
\hline Secondary school $3^{\text {rd }}$ grade & 115 & 13.5 & 195 & 22.8 & 310 & 36.3 \\
\hline \multicolumn{7}{|l|}{ Place of residence } \\
\hline Rural & 288 & 33.8 & 376 & 44 & 664 & 77.8 \\
\hline Urban & 81 & 9.5 & 109 & 12.7 & 190 & 22.2 \\
\hline \multicolumn{7}{|l|}{ BMI classification* } \\
\hline Underweight & 8 & 0.9 & 16 & 1.8 & 24 & 2.8 \\
\hline Normal & 242 & 28.4 & 373 & 43.7 & 615 & 72.1 \\
\hline Overweight & 80 & 9.4 & 73 & 8.5 & 153 & 17.9 \\
\hline Obese & 39 & 4.6 & 23 & 2.7 & 62 & 7.3 \\
\hline Total & 369 & 43.3 & 485 & 56.7 & 854 & 100 \\
\hline
\end{tabular}


weight and obese according to the reference values of BMI-for-age (5 to 19 years) z-scores for boys and girls proposed by the WHO (2007) (Table 1).

\section{Data analysis}

The survey results were analysed by cross tabulation method using pivot table function in the Microsoft Excel 2010 and expressed as average or the percentage of participants based on BMI-for-age, gender and educational stage. The potential relationships between BMI-forage and categorical variables such as choice of snack, frequency of meals consumption and selected products consumption as well as eating outside home were determined by Pearson's chi-square test ( $\chi$-test) (McHugh, 2013). The strength of the corresponding relationships was estimated by contingency coefficient assuming that a value below 0.1 indicates no or negligible relationship, whereas values between 0.1$0.3,0.3-0.5$ or above 0.5 indicate weak, moderate or a strong relationship, respectively (Baguley, 2012). A multinomial logistic regression model was computed in order to determine the association between BMI classification and continuous variables (Baguley, 2012) such as the average score for nutrition knowledge. The results of multinomial logistic regression were presented as exp $\beta$ which represents odds ratios (OR) with $95 \%$ confidence intervals (CI). The statistical analysis was conducted by using IBM SPSS Statistics software (IBM Corporation, Armonutrition knowledge, USA) with the pre-defined 95\% confidence interval $(\mathrm{p}<0.05)$.

\section{RESULTS}

\section{Studied population basic characteristics}

The majority of the surveyed population comprised of elementary school participants (32.4\% and $31.3 \%$ from $5^{\text {th }}$ and $7^{\text {th }}$ grade, respectively) followed by secondary school participants $(36.3 \%)$. Considering gender, girls were more numerous regardless of the educational stage (Table 1). Regarding the place of residence, participants were mostly settled in rural area (77.8\%). Furthermore, according to the BMI classification, participants with normal nutritional status were the most numerous $(72.1 \%)$ regardless of gender. Participants with overweight nutritional status were the second largest group in the studied population with $17.9 \%$. Furthermore, $7.3 \%$ of the adolescents were obese and $2.8 \%$ underweight (Table 1).

The prevalence of normal nutritional status rises steadily among educational stages with $68 \%$ of $5^{\text {th }}$ grade participants and $79 \%$ of the secondary school participants. Moreover, the highest share of obese nutritional status was observed among participants attending $5^{\text {th }}$ grade of elementary school $(11 \%)$ while the overweight nutritional status was the most common in the $7^{\text {th }}$ grade of elementary school (22.9\%). The distribution of participants with underweight nutritional status was approximately uniform across the examined educational stages.

\section{Dietary habits}

The daily consumption of breakfast, lunch, and dinner observed among adolescents in this study was $46.37 \%, 44.15 \%, 36.65 \%$ respecttively. The consumption frequencies of main meals and/or snacks throughout the week concerning BMI are presented in Figure 1. Lunch was the most regularly consumed meal among all participants, followed by dinner, breakfast and snack. The pattern of regular breakfast daily was practised in the highest share by underweight nutritional status participants $(66.67 \%)$ followed by obese, normal and overweight nutritional statuses. Breakfast skipping was also reported by participants from all nutritional status groups but slightly more pronounced for participants from underweight and obese nutritional status groups $(12.5 \%$ and $11.29 \%$, respectively). Moreover, more than $10 \%$ of participants from overweight and obese nutritional status groups reported less frequent breakfast consumption (two and five times weekly, Figure 1).

Conversely, lunch was the most regularly consumed meal regardless of the nutritional status group with $\sim 80 \%$ share (Figure 1). Regular dinner consumption was reported in the highest share by underweight nutritional status participants followed by normal status participants $(\sim 62 \%)$. However, a reduced number of dinners were noticed for participants in overweight and obese nutritional status groups. Participants from the overweight group more often skipped dinner or had dinner once a week while participants from the obese group reported eating dinner five times weekly at the highest share (Figure 1). A statistically significant but weak association between BMI and 

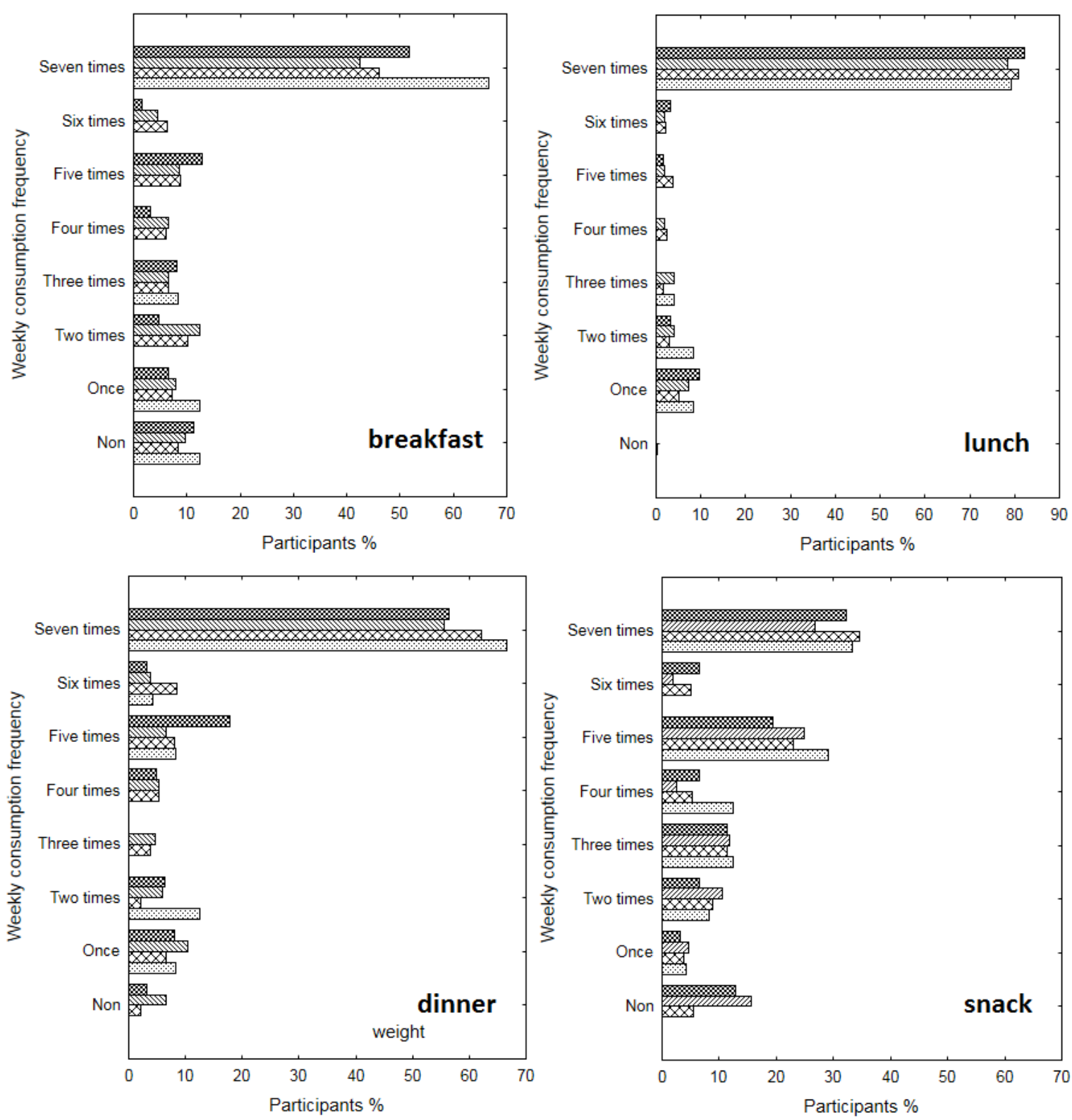

Underweight Normal

Figure 1. The weekly consumption frequency of meals according to the BMI-for-age

dinner consumption frequency was observed ( $\mathrm{p}=0.009$, contingency coefficient $=0.140$, Table 2). The average weekly lunch consumption among participants from different grades was identical (6.2 times), while a slight decrease was noticed in breakfast and dinner consumption among participants in higher educational stages. As regards gender, weekly lunch and dinner consumption was higher for boys compared to girls, while weekly breakfast consumption was identical for both genders. The snack consumption frequency at least once per day was reported by $34.6 \%$ of normal participants followed by participants from underweight, obese and overweight nutritional status groups. Moreover, snack consumption five times weekly was also frequently reported (19-28\%) by participants from all nutritional status groups while snack skipping was the most pronounced for overweight (7.19\%) and obese (6.45\%) nutritional status participants (Figure 1). The most often consumed snack among the normal nutritional status group were fruits (44.5\%) followed by salty snacks $(27.2 \%)$, sweets 
(11.9\%), cereals/muesli (4.9\%), and supplements $(1.95 \%)$ (Figure S1, supplementary material). Compared to other nutritional status groups, difference regarding snack choice was noted for the obese group were sweets came in fourth place (12.9\%), and the overweight group were sweets occupy fifth place $(5.23 \%)$. Regardless of the educational stage, fruits and salty snack came in the first and second place, respectively, but with opposite tendencies, while considering gender, snack choices were identical and correspond to the normal nutritional status group (refer to Figure S1 in the supplementary material for details). The choice of snack appeared as a factor with potential influence on participant's nutritional status since the statistically significant association with BMI was observed $(\mathrm{p}=0.003$, contingency coefficient $=0.203$, Table 2 ).

Participants in higher educational stages evinced more seldom preference towards fruit (decrease from $51.3 \%$ to $37.4 \%$ ) while conversely salty snack was more often chosen (an increase from $18.8 \%$ to $28.7 \%$ ). Furthermore, sweets as a snack were more preferred among $7^{\text {th }}$ grade elementary school participants and $3^{\text {rd }}$ grade secondary school participants (positioned in third place with $9.3 \%$ and $17.1 \%$ share, respectively), while $5^{\text {th }}$ grade participants preferred cereals instead $(10.5 \%)$. In addition, $3^{\text {rd }}$ grade secondary school participants excluded snack from the diet more often $(7.1 \%)$ compared to participants from other grades. Considering gender, snack choices were identical and correspond to the normal nutritional status group.

Furthermore, an average weekly consumption frequency for fruits and vegetables, chocolate and salty snack as well as eating in fast food, bakery and restaurants were observed concerning BMI, educational stage and gender (Figure S2, supplementary material). Among all nutritional status groups, fruits and vegetables were consumed weekly more than 4.3 times especially among participants with overweight nutritional status (4.7 times). Reported salty snack and chocolate weekly consumption frequencies were similar 1.46 and 1.3 times, respectively for normal status participants, followed by obese status participants (1.3 and 1.23 times, respectively), and overweight status participants (1.17 and 1.13 times, respectively). Statistically significant but weak dependence between BMI and frequency of snack consumption was noted only for salty snack consumption ( $\mathrm{p}=0.048$, contingency coefficient $=0.149$, Table 2 ).

Considering the educational stage, a decrease in consumption frequencies for all mentioned snacks was noted with a higher educational stage. Participants from $5^{\text {th }}$ grade consumed fruit and vegetables five times weekly, while among secondary school participants the average weekly consumption was 4.1 .

Table 2.

Results from chi-square test of independence revealing associations between BMI-for-age and examined determinants

\begin{tabular}{|c|c|c|c|c|c|}
\hline Variables & $\begin{array}{l}\text { Pearson's chi- } \\
\text { square value }\end{array}$ & df & Sig. & $\begin{array}{l}\text { Monte Carlo Sig. } \\
\text { (99\% confidence } \\
\text { interval) }\end{array}$ & $\begin{array}{l}\text { Contingency } \\
\text { coefficient }\end{array}$ \\
\hline Choice of snack & $33.97^{\mathrm{a}}$ & 15 & $0.003 *$ & $0.006(0.004-0.008)$ & 0.203 \\
\hline \multicolumn{6}{|c|}{ Consumption frequency of: } \\
\hline Breakfast & 7.525 & 6 & 0.275 & $0.274(0.263-0.285)$ & 0.094 \\
\hline Lunch & 5.921 & 6 & 0.432 & $0.427(0.414-0.440)$ & 0.083 \\
\hline Dinner & 16.992 & 6 & $0.009 *$ & $0.011(0.008-0.013)$ & 0.140 \\
\hline \multicolumn{6}{|l|}{$\begin{array}{l}\text { Consumption/visiting } \\
\text { frequency of: }\end{array}$} \\
\hline Fruits and vegetables & $5.296^{\mathrm{a}}$ & 9 & 0.808 & $0.803(0.793-0.814)$ & 0.083 \\
\hline Chocolate & $7.380^{\mathrm{a}}$ & 9 & 0.598 & $0.588(0.576-0.601)$ & 0.098 \\
\hline Salty snack & $17.030^{\mathrm{a}}$ & 9 & $0.048 *$ & $0.050(0.044-0.055)$ & 0.149 \\
\hline Fast-food restaurant & $17.275^{\mathrm{a}}$ & 9 & $0.045^{*}$ & $0.055(0.049-0.061)$ & 0.147 \\
\hline Bakery & 13.736 & 9 & 0.132 & $0.129(0.120-0.137)$ & 0.129 \\
\hline Restaurant & $11.573^{\mathrm{a}}$ & 9 & 0.238 & $0.227(0.216-0.238)$ & 0.122 \\
\hline
\end{tabular}


Higher consumption frequency for salty snack and chocolate was also noticed among $5^{\text {th }}$ grade participants (1.47 and 1.39 times weekly, respectively) compared to other grades (refer to Figure S2 in the supplementary material for details).

As regards gender, on a weekly average, fruits and vegetables were also the most often consumed but in slightly higher frequency among girls (4.7 times) compared to boys (4.2 times). Conversely, boys were slightly more prone to eat the entire chocolate (1.36 times per week) compared to girls (1.23 times per week), while the difference in the frequency of salty snacks consumption was negligible (1.4 times per week).

Regardless of nutritional status, the bakery was the most often choice for having a meal (1.3-1.8 times) followed by fast food (0.8-1.4 times) and restaurants (0.37-0.84 times) (refer to Figure S2 in the supplementary material for details). The bakery was the most frequently visited by normal status participants while fast-food restaurants and restaurants were the most frequently visited by participants from the obese nutritional status group. A statistically significant but weak relationship between BMI and eating fast food was observed $(\mathrm{p}=0.045$, contingency coefficient $=0.147$, Table 2). Conversely to restaurants, an increased tendency of eating in the bakery was observed with a higher educational stage. As regards fast food, the most frequent were participants from secondary school (1.02 times weekly). Considering gender, boys were more prone to eat fast food (1.1 times weekly) compared to girls (0.7 times weekly).

\section{Nutrition knowledge}

Participants' perception of basic food nutrients amounts needed in daily diet according to BMI classification, educational stage and gender is presented in Table 3. Regardless of BMI classification, educational stage and gender, the highest share of participants considered water as the main nutrition need. However, alarming results were obtained regarding carbohydrates since less than $10 \%$ of participants positioned carbohydrates as the second required nutrient in the diet. More often second place was occupied by vitamins. Proteins were considered as the third needed nutrient regarding amount by the majority of participants while less than $10 \%$ of participants positioned fats in fourth place.

About $20 \%$ of participants based on BMI classification, educational stage and gender, positioned dietary fibres in fifth place. Participants assigned higher importance to vitamins than the regular sixth place as well as to minerals. Considering BMI classification, participants with normal nutritional status were the ones with mostly provided adequate answers except in the case of proteins and vitamins (due to the small share of participants with underweight nutritional status results were considered negligible). Furthermore, at the higher education stage better knowledge about food nutrients require-

Table 3.

Participants' ranking on required amounts of basic food nutrients in daily diet according to BMI classification, educational stage and gender

\begin{tabular}{|c|c|c|c|c|c|c|c|}
\hline 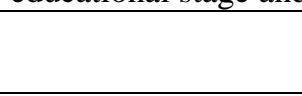 & Water & $\begin{array}{c}\text { Carbo- } \\
\text { hydrates }\end{array}$ & Proteins & Fats & $\begin{array}{c}\text { Dietary } \\
\text { fibres }\end{array}$ & Vitamins & Minerals \\
\hline \multicolumn{8}{|l|}{ Gender (\%) } \\
\hline Boys & 37.13 & 8.40 & 20.33 & 8.94 & 14.91 & 5.69 & 12.20 \\
\hline Girls & 42.27 & 8.66 & 21.86 & 5.98 & 19.38 & 3.92 & 10.10 \\
\hline \multicolumn{8}{|c|}{ BMI classification $(\%)$} \\
\hline Underweight & 25.00 & 4.17 & 8.33 & 8.33 & 20.83 & 0.00 & 12.50 \\
\hline Normal & 42.93 & 9.27 & 21.79 & 8.13 & 18.86 & 4.88 & 11.22 \\
\hline Overweight & 35.95 & 8.50 & 17.65 & 4.58 & 11.76 & 5.88 & 10.46 \\
\hline Obese & 27.42 & 3.23 & 29.03 & 4.84 & 16.13 & 1.61 & 9.68 \\
\hline \multicolumn{8}{|c|}{ Educational stage (\%) } \\
\hline $\begin{array}{l}\text { Elementary school } \\
5^{\text {th }} \text { grade }\end{array}$ & 36.82 & 5.78 & 14.8 & 5.05 & 13.72 & 2.17 & 12.64 \\
\hline $\begin{array}{l}\text { Elementary school } \\
7^{\text {th }} \text { grade }\end{array}$ & 35.96 & 6.74 & 22.85 & 5.99 & 19.1 & 4.49 & 9.36 \\
\hline $\begin{array}{l}\text { Secondary school } \\
3^{\text {rd }} \text { grade }\end{array}$ & 46.45 & 12.58 & 25.48 & 10.32 & 19.35 & 7.1 & 10.97 \\
\hline
\end{tabular}


Table 4.

Provided answers reporting the content of particular food nutrients in selected foodstuff pairs

\begin{tabular}{|c|c|c|c|c|c|c|c|c|c|}
\hline & \multicolumn{3}{|c|}{ "Good" fats content } & \multicolumn{3}{|c|}{ Dietary fibres content } & \multicolumn{3}{|c|}{ Water content } \\
\hline & fish & pork & n.d. & $\begin{array}{l}\text { white } \\
\text { bread }\end{array}$ & $\begin{array}{c}\text { wholemeal } \\
\text { roll }\end{array}$ & n.d. & bread & $\begin{array}{l}\text { toast } \\
\text { bread }\end{array}$ & n.d. \\
\hline \multicolumn{10}{|l|}{ Gender (\%) } \\
\hline Boys & 54.74 & 14.63 & 30.62 & 27.1 & 42.28 & 30.62 & 55.83 & 13.82 & 30.35 \\
\hline Girls & 66.19 & 13.2 & 20.62 & 19.79 & 57.73 & 22.47 & 61.65 & 17.73 & 20.62 \\
\hline \multicolumn{10}{|c|}{ BMI classification $(\%)$} \\
\hline Underweight & 66.67 & 12.5 & 20.83 & 37.5 & 41.67 & 20.83 & 50.00 & 29.17 & 20.83 \\
\hline Normal & 63.09 & 14.31 & 22.60 & 24.55 & 51.87 & 23.58 & 61.95 & 15.93 & 22.11 \\
\hline Overweight & 54.9 & 12.42 & 32.68 & 16.34 & 50.98 & 32.68 & 52.29 & 14.38 & 33.33 \\
\hline Obese & 56.45 & 12.9 & 30.65 & 17.74 & 46.77 & 35.48 & 51.61 & 16.13 & 32.26 \\
\hline \multicolumn{10}{|c|}{ Educational stage (\%) } \\
\hline $\begin{array}{l}\text { Elementary school } \\
5^{\text {th }} \text { grade }\end{array}$ & 45.13 & 15.52 & 39.35 & 24.91 & 33.57 & 41.52 & 50.54 & 10.47 & 38.99 \\
\hline $\begin{array}{l}\text { Elementary school } \\
7^{\text {th }} \text { grade }\end{array}$ & 61.42 & 15.34 & 23.22 & 26.59 & 49.87 & 23.60 & 62.92 & 13.48 & 23.60 \\
\hline $\begin{array}{l}\text { Secondary school } \\
3^{\text {rd }} \text { grade }\end{array}$ & 75.48 & 10.97 & 13.55 & 18.06 & 67.74 & 14.19 & 63.55 & 23.23 & 13.23 \\
\hline
\end{tabular}

ments and recommended consumption was noticed. As regards gender, similar results were noted, except for dietary fibres where girls provided the adequate answer in a higher percentage (Table 3).

Participants' answers provided for specified food nutrients content in selected foodstuff concerning BMI classification, educational stage and gender are presented in Table 4. As a source of "good" fats between fish and pork, more than $54 \%$ of participants declared for fish, regardless of nutritional status group. The presence of a higher dietary fibre amount in a wholemeal roll rather than in white bread was reported by more than $41 \%$ of participants from all nutritional status groups. Furthermore, the higher water content in bread than in toast bread was reported by more than $50 \%$ of participants regardless of nutritional status (Table 4).

Regardless of the educational stage, a higher percentage of participants provided correct answers on corresponding nutrients content in selected foodstuff pairs. Moreover, the percentage of correct foodstuff choice increased with a higher educational stage (Table 4). However, it was also noticed that a considerable number of participants avoided answering the asked question (n.d., Table 4). Regarding gender, girls in a slightly higher share responded correctly to the corresponding question compared to boys (Table 4).
Provided answers regarding definitions of wholemeal bread and vitamin deficiency according to BMI classification are presented in Figure 2. About $50 \%$ of participants from the overweight and obese group associated wholemeal bread with bread which is adequate for a special diet without gluten, while $45 \%$ of participants from both groups marked proper definition which is bread obtained from wholemeal flour (Figure 2, left). Normal status participants answered correctly to the corresponding question in the highest share $(50 \%)$. As regards to the educational stage, participants from the $3^{\text {rd }}$ grade of secondary school responded correctly in the highest share, followed by participants from the $5^{\text {th }}$ and $7^{\text {th }}$ elementary school grades. Considering gender, girls were more familiar with the definition of wholemeal bread than boys ( $51.8 \%$ and $45 \%$, respectively).

Addressing the question regarding vitamin deficiency, participants from the normal nu-tritional status group opted for the answer "complete deficiency of vitamin in the body" in the highest share followed by participants from the underweight, overweight and obese group (Figure 2, right). Furthermore, $45 \%$ of participants from the obese nutritional status group marked that they did not know the answer to the corresponding question as well as $45.8 \%$ of participants from the underweight nutritional status 


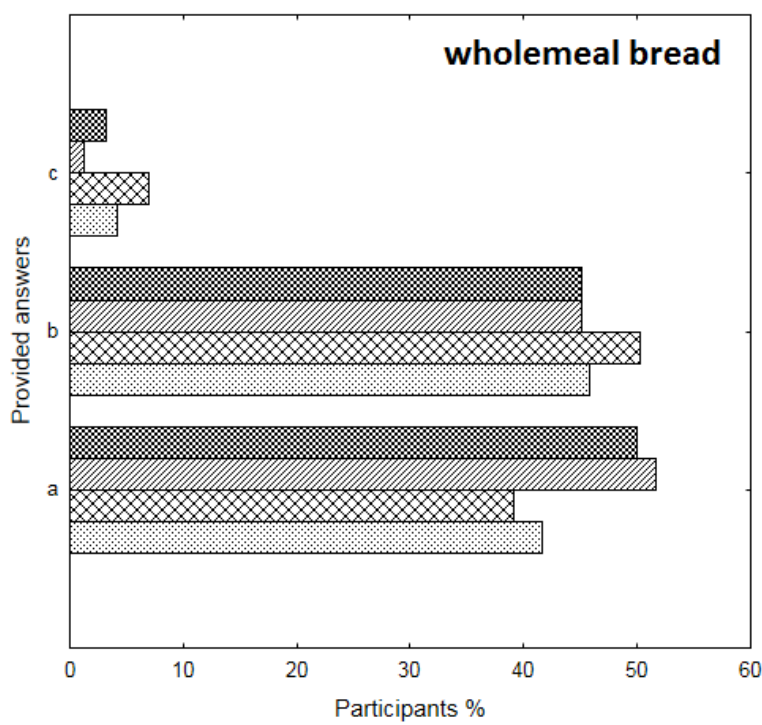

Underweight

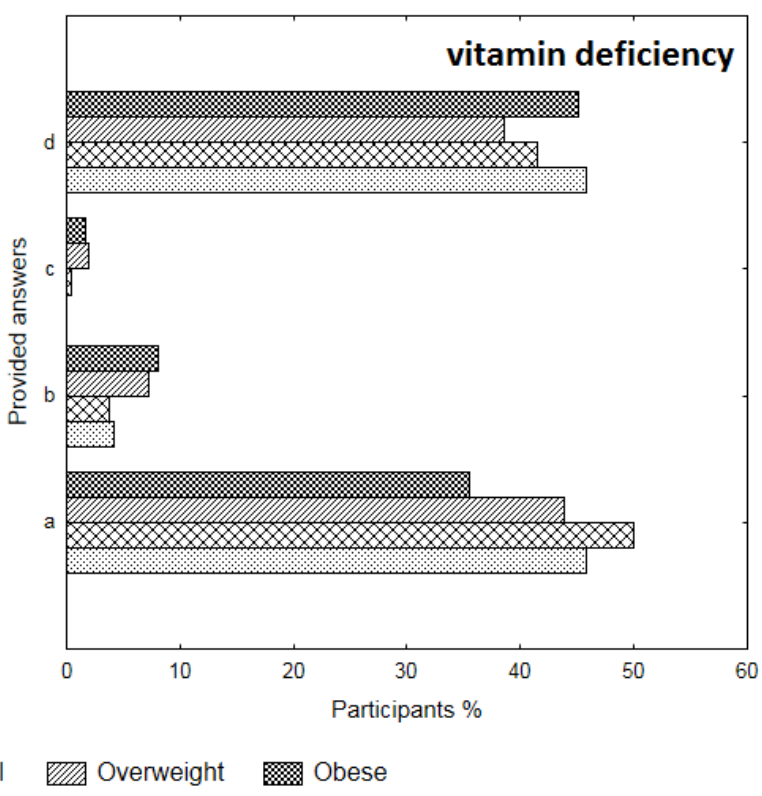

Figure 2. Participants' responses regarding definitions of wholemeal bread and vitamin deficiency, left-a) bread adequate for special diet without gluten b) bread obtained from wholemeal flour c) bread which contains various additives; right-a) complete deficiency of a vitamin in the body b) sufficient amount of vitamin A in the body c) bone disease d) do not know

Table 5.

Multinomial logical regression model results for the association between adolescents' BMI nutritional status group with average nutrition knowledge

\begin{tabular}{lcccccc}
\hline BMI classification & $\boldsymbol{\beta}$ & $\begin{array}{c}\text { Std. } \\
\text { Error }\end{array}$ & Wald $\chi^{\mathbf{2}}$ & df & Sig. & $\begin{array}{c}\text { exp. } \boldsymbol{\beta} / \mathbf{O R} \\
\mathbf{( 9 5 \%} \text { CI })\end{array}$ \\
\hline Nutrition knowledge $^{\mathrm{a}}$ & & & & & & \\
\hline Underweight $_{\text {Normal }}$ & 0.051 & 1.426 & 0.001 & 1 & 0.971 & $1.053(0.064-17.209)$ \\
Overweight & 1.881 & 0.793 & 5.633 & 1 & $0.018^{*}$ & $6.563(1.388-31.037)$ \\
\hline
\end{tabular}

${ }^{a}$ The reference BMI category for nutrition knowledge is Obese

group (Figure 2, right). Girls responded correctly regarding vitamin deficiency definition in higher share compared to boys $(50.3 \%$ versus 44.25 , respectively) while with higher educational stage number of correct answers by participants increased.

Two multinomial logistic regression models were established to estimate the association between adolescents' BMI nutritional status group and average nutrition knowledge (Table 5). A statistically significant regression coefficient was obtained for the normal nutritional status group ( $\mathrm{p}=0.018$, Table 5) regarding average nutrition knowledge by using the obese nutritional status group as reference. Adolescents reporting higher average nutrition knowledge scores by one unit were 6.56 times $(95 \%$ CI, 1.388-31.037, Table 5) more likely to be in the normal nutritional status group rather than obese.

\section{DISCUSSION}

The presented study encloses the key factors considered as precursors of healthy diet development among adolescents through questions regarding meal consumption regularity and snack choices as well as basic food nutrients necessity. As a cross-sectional study, the study aimed to describe the possible relationships between mentioned factors and Serbian adolescents BMI.

Most of the adolescents belonged to the normal nutritional status group (72 \%) which is in agreement with previous findings of Rakic, Bozic-Krstic \& Pavlica (2011) obtained for a wider studied population in the Vojvodina region. Nevertheless, the obtained share of overweight and obese adolescents in the presented study was higher for $7.9 \%$ and $2.3 \%$, respectively compared to those reported by Rakic et al. (2011) indicating a possible increase in the 
prevalence of adolescents' overweight and obesity in the Vojvodina region. However, compared to results from studies conducted in Italy (Grosso et al., 2012) and Greece (Karatzi, Moschonis, Choupi \& Manios, 2017) the corresponding share is still lower. Furthermore, the resented study reveals that the prevalence of obesity was more pronounced among boys, which is consistent with findings of other authors (Grosso et al., 2012; Ramos, Brooks, GarcíaMoya, Rivera \& Moreno, 2013; Karatzi et al. 2017), as well as among participants from $5^{\text {th }}$ grade of elementary school.

The daily consumption of breakfast, lunch, and dinner observed in this study was lower compared to that observed for adolescents from Sweden (Sjöberg, Hallberg, Hoglund \& Hulthen, 2003), Scotland (Macdiarmid et al., 2009), and Brazil (Estima et al., 2009; Rodrigues et al., 2017). An unsatisfactory meal profile was noted since more than half of the adolescents participating in this study reported adherence to the traditional three meals a day pattern followed by the majority of European students (Ayranci, Erenoglu \& Son, 2010). Consequently, skipping the day's main meals may have a deleterious effect on health and nutrition, more specifically higher levels of certain risk markers (e.g., triglycerides, cholesterol, and glucose metabolism) for long-term conditions development (obesity, type 2 diabetes, cardiovascular disease) (Murakami \& Livingstone, 2016). Although no significant association was found between BMI and the frequency of breakfast consumption in this study, more than $10 \%$ of participants from overweight and obese nutritional status groups reported reduced breakfast consumption (two and five times weekly). Many previous studies confirmed (Grosso et al., 2012; Jääskeläinen et al., 2013), but also neglected (Hopkins, Sattler, Anderson Steeves, Jones-Smith \& Gittelsohn, 2017) the relationship between BMI and breakfast consumption for both adolescents and adults. Our findings on the corresponding relationship contribute to the arising evidence that frequency of breakfast consumption may not be the single factor affecting weight gain. Many studies investigated the frequency of dinner consumption, but a paucity of them proved the connection with BMI. Results from this study reveal a potential significant association between BMI and the frequency of dinner consumption ( $\mathrm{p}=0.009$; chi-square test). Habitually dinner skipping, more often practised by over- weight and obese participants in this study, can be the consequence of the predominant opinion that meals' skipping is a good weight loss strategy commonly practised among adolescents (Ramos et al., 2013). Additionally, there is another opinion that excess consumption of calories at dinner induces lower caloric intake at breakfast and a higher likelihood of breakfast skipping, again closely related to overweight and obesity in children with low physical activity levels (Karatzi et al., 2017).

Considering gender, irregular meal habits were more pronounced among girls compared to boys, in line with previous findings (Sjöberg et al., 2003; Macdiarmid et al., 2009; Rodriges et al., 2017).

Although a significant association was found between snack choice, salty snack and fast food consumption frequency and BMI $(\mathrm{p}=0.003$; $\mathrm{p}=0.048 ; \quad \mathrm{p}=0.045 ;$ chi-square test) certain health awareness among participating adolescents is noted since fruits and vegetables were the most often chosen snack. Furthermore, the fast food consumption frequency reported in this study (0.8-1.4 times weekly) was similar to results reported by Guiné et al. (2016) for Croatian and Macedonian adults (once a week) and lower than those reported for Denmark (Lassen et al., 2016). Adolescents with obese nutritional status in this study affirmed a higher likelihood of fast food consumption supporting the previous association found between BMI increase and increasing fast food consumption (Niemeier, Raynor, Lloyd-Richardson, Rogers \& Wing, 2006). Existing conflicting results presented in literature regarding snack foods and body weight impose the need to underline the importance of snack choice and its connection either with weight loss and maintenance (nutrient-dense snack foods-fruits, vegetables, unrefined cereal products) or with weight gain (energy-dense snack foods-sweets, salty snacks, fast food) (Njike et al., 2016) as highlighted in this study.

A decrease in healthy snack choice with educational stage increase was observed, since the highest share of salty snacks, sweets and fast food consumption was reported by secondary school adolescents. The corresponding results might be explained by the weakening of parental influence and greater independence of adolescents in higher grades. Nevertheless, they are still in contradiction with studies conducted 
in adults reporting that the higher educated people expressed more positive attitudes toward healthy eating (Lê et al., 2013). Differences in snack choice and frequency of snack consumption across genders were minimal, except for sweets and fast food which were more consumed by boys, which harmonizes with the findings of Larson et al. (2008).

Since proper nutrition knowledge represents a predisposing factor for healthy eating behaviours, the presented study was also undertaken to explore the nutritional knowledge of the Zoomers in Serbia.

Overall low scores obtained for required amounts of carbohydrates and fats across the studied population, provides evidence that the exact role of these macronutrients in a healthy diet is unknown to Zoomers and proper measures must be undertaken to improve this result. The results addressing the nutrition knowledge across nutritional status groups pointed out that adolescents' with normal nutritional status showed better knowledge regarding required basic food nutrients amounts, food nutrients content in selected foodstuff, definitions of wholemeal bread and vitamin deficiency compared to adolescents with obese nutritional status. Furthermore, the statistically significant association between nutritional knowledge and adolescents with normal nutritional status imply that an increase in overall knowledge score for one unit increases the possibility of having normal weight for 6.56 times. Conversely to our findings, there was no convincing correlation between nutritional status groups and nutrition knowledge in the HELENA study conducted across Europe (Sichert-Hellert et al., 2011), except the pilot study where a tendency for lower nutrition knowledge scores with increasing BMI was noted only for girls (Kersting et al., 2008). Inclusion of nutritional status group without other variables (educational stage, parental education, socio-economic status) in the model for the nutrition knowledge estimation could be the explanation for these conflicting results. Concerning the educational stage, nutritional knowledge scores for each question increased with the educational stage increase. This harmonizes with results reported in the literature (Sichert-Hellert et al., 2011; Grosso et al., 2012), underlying that nutritional knowledge increased with increasing age and type of school in the European adolescent popu- lation. A higher percentage of correct answers for questions addressing nutrition knowledge were recorded for girls, which is in agreement with previous studies (Kersting et al., 2008; Sichert-Hellert et al., 2011). This is not a surprising result taking into account that girls are more involved in the meal preparation and care for their health and physical appearance at an earlier age than boys (Sichert-Hellert et al., 2011).

Nevertheless, the presented results should be considered in light of several limitations. Firstly, this study was a cross-sectional study hence it only makes inferences about possible relationships between examined determinants and prevalence of obesity development. Secondly, the used questionnaire for the assessment of adolescents' dietary habits and nutrition knowledge was not fully validated only revised and previously tested on a small group of participants without subsequent statistical analysis. Nevertheless, examined habits and behaviours were relevant because they were previously confirmed as those which might lead to eating disorders and obesity (Miccoli et al., 2018). Furthermore, the accuracy of the self-reported anthropometric data depends on various factors such as frequency of control, and willingness to report accurate data, hence reporting bias cannot be excluded. Another bias that should be taken into account is the social acceptability bias related to reported anthropometric data as well as other provided answers (Grosso et al., 2012). However, great interest was established for this kind of results regarding the particular adolescent group such as generation $\mathrm{Z}$. This alongside anonymity as an important factor for gathering honest answers as well as participants unfamiliarity regarding the exact time of the survey conduction under teachers supervision, represent the study's strengths.

\section{CONCLUSIONS}

The presented study, considering the abovementioned limitations, gave an insight into nutrition knowledge, and dietary habits of generation $\mathrm{Z}$, living in the Autonomous Province of Vojvodina, Serbia and their potential association with the prevalence of obesity. Study results reveal an increasing prevalence of overweight (from $10 \%$ to $17.9 \%$ ) and obese (from $5 \%$ to $7.3 \%$ ) adolescents in Serbia in the past fifteen years. 
Despite the modest nutrition knowledge observed in general, the alarming fact is that less than $10 \%$ of adolescents were familiar with the necessary amount of car-bohydrates and fats needed in daily diet. Additionally, overweight and obese adolescents showed inferior nutrition knowledge compared to other BMI groups, as well as lower grade adolescents and boys. Furthermore, although adolescents possess certain nutritional knowledge many of them fail to apply that knowledge in practice. Namely, a higher consumption frequency of unhealthy foods (sweets, salty snacks, fast food) among more educated and obese adolescents was recorded. Also, breakfast (53.63\%), lunch $(55.85 \%)$ and dinner (63.35\%) skipping among generation $\mathrm{Z}$ adolescents were recognised as common weight control strategy especially among girls. Finally, the potential link between nutrition knowledge and BMI established in this study allows us to conclude that better nutrition knowledge could have a positive impact on the risk of obesity development. The Serbian adolescents' lifestyle is changing alongside the undergoing changes in Serbia as a developing country, another factor that should be accounted for when addressing obesity.

\section{ACKNOWLEDGEMENTS}

This work was supported by the Ministry of Education, Science and Technological Development of the Republic of Serbia [grant number 451-03-68/2020-14/200134]. The authors are thankful for the sincere contributions regarding questionnaire development to prof. dr Peter Raspor and prof. dr Sonja Smole Možina from the Biotechnical Faculty, University of Ljubljana and dr Andrej Ovca from the Faculty of Health Sciences, University of Ljubljana.

\section{REFERENCES}

Alčaković, S. (2019). The Generation Z in Serbia: Ready for the great opening. In Scholz C. \& Rennig A. (Eds.), Generations $Z$ in Europe (The Changing Context of Managing People) (pp. 199-216). United Kingdom: Emerald Publishing Limited. https://doi.org/10.1108/978-1-78973-491-120191018

Alexy, U., Wicher, M., \& Kersting, M. (2010). Breakfast trends in children and adolescents: Frequency and quality. Public Health Nutrition, 13(11), 1795-1802. https://doi.org/10.1017/S1368980010000091

Ayranci, U., Erenoglu, N., \& Son, O. (2010). Eating habits, lifestyle factors, and body weight status among Turkish private educational institution students. Nutrition, 26(7-8), 772-778.

https://doi.org/10.1016/j.nut.2009.07.007
Baguley, T. (2012). Serious stats: A guide to advanced statistics for the behavioral sciences. London, UK: Macmillan International Higher Education.

Bahia, L., Schaan, C. W., Sparrenberger, K., Abreu, G. A., Barufaldi, L. A., Coutinho, W., \& Schaan, B. D. (2019). Overview of meta-analysis on prevention and treatment of childhood obesity. Jornal de Pediatria, 95(4), 385-400. https://doi.org/10.1016/j.jped.2018.07.009

Barr, S. I. (2006). Introduction to Dietary Reference Intakes. Applied Physiology, Nutrition, and Metabolism, 31(1), 61-65. https://doi.org/10.1139/h05-019

Craigie, A. M., Lake, A. A., Kelly, S. A., Adamson, A. J., \& Mathers, J. C. (2011). Tracking of obesity- related behaviours from childhood to adulthood: a systematic review. Maturitas, 70(3), 266-284. https://doi.org/10.1016/j.maturitas.2011.08.005

Estima, C. C., da Costa, R. S., Sichieri, R., Pereira, R. A., \& Veiga, G. V. (2009). Meal consumption patterns and anthropometric measurements in adolescents from a low socioeconomic neighborhood in the metropolitan area of Rio de Janeiro Brazil. Appetite, 52(3), 735-739. https://doi.org/10.1016/j.appet.2009.03.017

Grosso, G., Mistretta, A., Turconi, G., Cena, H., Roggi, C., \& Galvano, F. (2012). Nutrition knowledge and other determinants of food intake and lifestyle habits in children and young adolescents living in a rural area of Sicily, South Italy. Public Health Nutrition, 16(10), 1827-1836. https://doi.org/10.1017/S1368980012003965

Guiné, R. P. F., Duarte, J., Ferreira, M., Correia, P., Leal, M., Rumbak, I., Baric, I. C., Komes, D., Satalic, Z., Saric, M. M., Tarcea, M., Fazakas, Z., Jovanoska, D., Vanevski, D., Vittadini, E., Pellegrini, N., Szucs, V., Harangozó, J., EL-Kenawy, A., EL-Shenawy, O., Yalcin, E., Kösemeci, C., Klava, D., \& Straumite, E. (2016). Attitudes towards dietary fibre on a multicultural basis: A fibre study framework. Current Nutrition \& Food Science, 12(2), 132-141. https://doi.org/10.2174/157340131202160412171430

Hopkins, L. C., Sattler, M., Anderson Steeves, E., JonesSmith, J. C., \& Gittelsohn, J. (2017). Breakfast consumption frequency and its relationships to overall diet quality, using healthy eating index 2010, and body mass index among adolescents in a lowincome urban setting. Ecology of Food and Nutrition, 56(4), 297-311. https://doi.org/10.1080/03670244.2017.1327855

Jääskeläinen, A., Schwab, U., Kolehmainen, M., Kaakinen, M., Savolainen, M. J., Froguel, P., Cauchi, S., Järvelin, M-R., \& Laitinen J. (2013). Meal frequencies modify the effect of common genetic variants on body mass index in adolescents of the Northern Finland birth cohort 1986. PLoS One, 8(9), e73802. https://doi.org/10.1371/journal.pone.0073802

Karatzi, K., Moschonis, G., Choupi, E., \& Manios, Y. (2017). Late-night overeating is associated with smaller breakfast, breakfast skipping, and obesity in children: The Healthy Growth Study. Nutrition, 33, 141-144. http://dx.doi.org/10.1016/j.nut.2016.05.010

Kersting, M., Sichert-Hellert, W., Vereecken, C. A., Diehl, J., Béghin, L., De Henauw, S., Grammatikaki, E., Manios, Y., Mesana, M. I., Papadaki, A., Phillipp, K., Plada, M., Poortvliet, E., \& Sette, S. (2008). Food and nutrient intake, nutritional knowledge and 
diet-related attitudes in European adolescents. International Journal of Obesity, 32, S35-S41. https://doi.org/10.1038/ijo.2008.181

Larson, N. I., Neumark-Sztainer, D. R., Story, M. T., Wall, M. M., Harnack, L. J., \& Eisenberg, M. E. (2008). Journal of Adolescent Health, 43, 79-86. https://doi.org/10.1016/j.jadohealth.2007.12.005

Lassen, A. D., Lehmanna, C., Wreford, E. A., Werther, M. N., Thorsen, A. V., Trolle, E., Gross, G., \& Tetens, I. (2016). Gender differences in purchase intentions and reasons for meal selection among fast food customers - Opportunities for healthier and more sustainable fast food. Food Quality and Preference, 47, 123-129.

http://dx.doi.org/10.1016/j.foodqual.2015.06.011

Lê, J., Dallongeville, J., Wagner, A., Arveiler, D., Haas, B., Cottel, D., Simon, C., \& Dauchet, L. (2013). Attitudes toward healthy eating: A mediator of the educational level-diet relationship. European Journal of Clinical Nutrition, 67, 808-814.

https://doi.org/10.1038/ejcn.2013.110

Macdiarmid, J., Loe, J., Craig, L. C., Masson, L. F., Holmes, B., \& McNeill, G. (2009). Meal and snacking patterns of school-aged children in Scotland. European Journal of Clinical Nutrition, 63, 12971304. https://doi.org/10.1038/ejen.2009.87

McGuire, M. T., Wing, R. R., Klem, M. L., \& Hill, J. O. (1999). The behavioral characteristics of individuals who lose weight unintentionally. Obesity Research, $7(5), \quad 485-490 . \quad$ https://doi.org/10.1002/j.15508528.1999.tb00437.x

McHugh, M. L. (2013). The chi-square test of independence. Biochemia medica: Biochemia medica, 23(2), 143-149. https://doi.org/10.11613/BM.2013.018

Miccoli, L., Martínez-Fiestas, M., Delgado-Rodríguez, R., Díaz-Ferrer, S., Rodríguez-Ruiz, S., \& FernándezSantaella, M. C. (2018). Adolescent emotions toward sweet food cues as a function of obesity and risky dieting practices. Food Quality and Preference, 68, 205-214. https://doi.org/10.1016/j.foodqual.2018.03.006

Moreno, L. A., Rodriguez, G., Fleta, J., Bueno-Lozano, M., Lazaro, A., \& Bueno, G. (2010). Trends of dietary habits in adolescents. Critical Reviews in Food Science and Nutrition, 50(2), 106-112. https://doi.org/10.1080/10408390903467480

Murakami, K., \& Livingstone, M. B. (2016). Associations between meal and snack frequency and overweight and abdominal obesity in US children and adolescents from National Health and Nutrition Examination Survey (NHANES) 2003-2012. British Journal of Nutrition, 115, 1819-1829. https://doi.org/10.1017/S0007114516000854

Niemeier, H. M., Raynor, H. A., Lloyd-Richardson, E. E., Rogers, M. L., \& Wing, R. R. (2006). Fast food consumption and breakfast skipping: Predictors of weight gain from adolescence to adulthood in a nationally representative sample. Journal of Adolescent Health, 39, 842-849. https://doi.org/10.1016/j.jadohealth.2006.07.001

Njike, V. Y., Smith, T. M., Shuval, O., Shuval, K., Edshteyn, I., Kalantari, V., \& Yaroch, A. L. (2016). Snack food, satiety, and weight. Advances in Nutrition, 7(5), 866-878. https://doi.org/10.3945/an.115.009340
Rakic, R., Bozic-Krstic, V., \& Pavlica, T. (2011). Relationship between overweight, obesity and socioeconomic factors of adolescents in Vojvodina, Serbia. HOMO - Journal of Comparative Human Biology, 62, 307-313. https://doi.org/10.1016/j.jchb.2011.04.002

Ramos, P., Brooks, F., García-Moya, I., Rivera, F., \& Moreno, C. (2013). Eating habits and physical activity in dieter and non-dieter youth: A gender analysis of English and Spanish adolescents. The Social Science Journal, 50, 575-582. http://dx.doi.org/10.1016/j.soscij.2013.09.017

Rodrigues, P. R. M., Luiz, R. R., Monteiro, L. S., Ferreira, M. G., Gonçalves-Silva, R. M. V., \& Pereira, R. A. (2017). Adolescents' unhealthy eating habits are associated with meal skipping. Nutrition, 42, 114120. https://doi.org/10.1016/j.nut.2017.03.011

Rovner, A. J., Nansel, T. R., Wang, J., \& Iannotti, R. J. (2011). Food sold in school vending machines is associated with overall student dietary intake. Journal of Adolescent Health, 48(1), 13-19. http://dx.doi.org/10.1016/j.jadohealth.2010.08.021

Sichert-Hellert, W., Beghin, L., De Henauw, S., Grammatikaki, E., Hallström, L., Manios, Y., Mesana, M. I., Molnár, D., Dietrich, S., Piccinelli, R., Plada, M., Sjöström, M., Moreno, L. A., \& Kersting, M. (2011). Nutritional knowledge in European adolescents: results from the HELENA (Healthy Lifestyle in Europe by Nutrition in Adolescence) study. Public Health Nutrition, 14, 2083-2091. https://doi.org/10.1017/S1368980011001352

Sjöberg, A., Hallberg, L., Hoglund, D., \& Hulthen, L. (2003). Meal pattern, food choice, nutrient intake and lifestyle factors in The Göteborg Adolescence Study. European Journal of Clinical Nutrition, 57, 1569-1578. https://doi.org/10.1038/sj.ejcn.1601726

Stevenson, C., Doherty, G., Barnett, J., Muldoon, O. T., \& Trew, K. (2007). Adolescents' views of food and eating: Identifying barriers to healthy eating. Journal of Adolescence, 30(3), 417-434. https://doi.org/10.1016/j.adolescence.2006.04.005

Su C-H, Tsai C-H, Chen M-H, \& Lv W. Q. (2019). U.S. sustainable food market generation $\mathrm{Z}$ consumer segments. Sustainability, 11(13), 3607. https://doi.org/10.3390/su11133607

Timlin, M. T., Pereira, M. A., Story, M., \& NeumarkSztainer, D. (2008). Breakfast eating and weight change in a 5-year prospective analysis of adolescents: Project EAT (eating among teens). Pediatrics, 121(3), 638-645. https://doi.org/10.1542/peds.2007-1035

Ton Nu, C., MacLeod, P., \& Barthelemy, J. (1996). Effects of age and gender on adolescents' food habits and preference. Food Quality and Preference, 7, 251262.

Wang, Y., \& Zhang, Q. (2006). Are American children and adolescents of low socioeconomic status at increased risk of obesity? Changes in the association between overweight and family income between 1971 and 2002. The American Journal of Clinical Nutrition, 84(4), 707-716. https://doi.org/10.1093/ajcn/84.4.707

WHO (2005). Nutrition in adolescence: issues and challenges for the health sector: Issues in adolescent health and development. Retrieved from https://apps.who.int/iris/handle/10665/43342. 
WHO (2007). Growth reference 5-19 years. Geneva: World Health Organization. Retrieved from https://www.who.int/growthref/who2007_bmi_for_a ge_field/en/

WHO (2009). Which health problems affect adolescents and what can be done to prevent and respond to them? Child and adolescent health and development. Retrieved from http://www.who.int/child adolescent health/topics/prevention care/adolescent/ de/en/

\section{SUPPORTING INFORMATION}

Additional Supplementary material may be found in the online version of this article.

Figure S1. Participants' snack choices regarding gender, nutritional status and educational stage

Figure S2. Participants' consumption frequency of selected snacks and eating outside home regarding gender, nutritional status and educational stage 


\section{USKLAĐIVANJE ZNANJA O PRAVILNOJ ISHRANI I NAVIKA U ISHRANI GENERACIJE Z - POSTOJI LI MOGUĆNOST ZA UNAPREĐENJE?}

Szabolcs Halasi ${ }^{1}$, Miljana Z. Đorđević ${ }^{2 *}$, Ferenc E. Kiš ${ }^{3}$, Dragana M. Šoronja-Simović ${ }^{2}$, Nikola R. Maravić Olga Horvat $^{4}$, Žana Šaranović ${ }^{5}$

${ }^{1}$ Univerzitet u Novom Sadu, Učiteljski fakultet na mađarskom nastavnom jeziku, Katedra za stručno-umetničke predmete i fizičko vaspitanje, 24000 Subotica, Štrosmajerova 11, Srbija

${ }^{2}$ Univerzitet u Novom Sadu, Tehnološki fakultet, Katedra za inženjerstvo ugljenohidratne hrane, 21000 Novi

Sad, Bul. cara Lazara 1, Srbija

${ }^{3}$ Univerzitet u Novom Sadu, Tehnološki fakultet, Katedra za opšte inženjerske discipline, 21000 Novi Sad, Bul. cara Lazara 1, Srbija

${ }^{4}$ Univerzitet u Novom Sadu, Medicinski fakultet, Katedra za farmakologiju i toksikologiju, 21000 Novi Sad, Hajduk Veljkova 3, Srbija

${ }^{5}$ Ekonomski institut, 11000 Beograd, Kralja Milana 16, Srbija

Sažetak: U prikazanoj studiji istražena je potencijalna povezanost znanja o ishrani i prehrambenih navika sa razvojem gojaznosti kod adolescenata generacije Z. Kroz upitnik dizajniran od strane autora, podaci o učestalosti konzumiranja obroka, izboru grickalica i poznavanju neophodnih količina osnovnih hranljivih sastojaka u ishrani prikupljeni su od 854 učenika (11-18 godina) osnovnih i srednjih škola u Autonomnoj Pokrajini Vojvodina. Podaci su analizirani i razmatrana je njihova povezanost prvenstveno sa indeksom telesne mase, a zatim polom i stepenom obrazovanja. Povezanost indeksa telesne mase i ispitivanih odrednica testirana je korišćenjem Hi-kvadrata i logističke regresije. Iako je većina ispitanih adolescenata imala normalnu telesnu težinu $(72,1 \%)$, otkriven je i značajan udeo adolescenata sa prekomernom težinom $(17,9 \%)$. Pored toga, uočene nepravilnosti u učestalosti konzumiranja doručka i večere kao i skromno znanje učesnika o pravilnoj ishrani mogu dalje doprineti pogoršanju ishrane. Zabeležene su statistički značajne, ali slabe veze između indeksa telesne mase i izbora užine, učestalosti konzumiranja večere kao i učestalosti konzumiranja slanih grickalica i brze hrane. Takođe, utvrđena je obrnuta proporcionalnost između višeg nivoa znanja o ishrani i prevalencije gojaznosti (OR 6.56, 95\% CI 1.388-31.037).

Kao rezultat, uočena je potreba za poboljšanjem prvenstveno znanja o pravilnoj ishrani, što predstavlja zadatak koji treba ostvariti kroz razvoj strategije za promociju zdravlja među Generacijom Z.

Ključne reči: generacija Z, znanje o pravilnoj ishrani, indeks telesne mase, učestalost obroka, gojaznost

Received: 12 February 2021/Received in revised form: 23 April 2021/ Accepted: 31 May 2021

Available online: June 2021

This is an open-access article under the CC BY license (http://creativecommons.org/licenses/by/3.0). 